\title{
Spatial and Temporal Expression of Acetylcholine Receptor RNAs in Innervated and Denervated Rat Soleus Muscle
}

\author{
Daniel Goldman and Julie Staple \\ Mental Health Research Institute \\ and Department of Biological Chemistry \\ The University of Michigan \\ Ann Arbor, Michigan 48109
}

\section{Summary}

In adult vertebrate skeletal muscle acetylcholine receptors are localized to the neuromuscular junction. Upon denervation, this distribution changes, with new receptors appearing in extrajunctional regions of the muscle fiber. The location of acetylcholine receptors in innervated or denervated muscle may result, in part, from the distribution of their RNAs. This was tested by assaying for receptor RNAs in junctional and extrajunctional regions of innervated and denervated rat soleus muscle using in situ hybridization and RNAase protection assays. These experiments showed $\alpha, \beta$, and $\delta$ subunit RNAs concentrated beneath the endplates of innervated muscle fibers. Following denervation, there was an unequal distribution of receptor RNAs along the muscle fiber, with highest levels occurring in extrajunctional regions near the endplate. These data are consistent with a nonuniform pattern of gene expression in adult skeletal muscle fibers.

\section{Introduction}

Communication throughout the nervous system takes place at specialized regions of the cell referred to as the synapse. The mechanism for generating this specialized structure is not known. The neuromuscular junction provides an ideal system for studying synapse formation and the influence a presynaptic neuron has on organizing the postsynaptic structure. The nicotinic acetylcholine receptor ( $\mathrm{A} A \mathrm{ChR}$ ) is an excellent marker for postsynaptic differentiation. It is an integral membrane protein with a stoichiometry of $\alpha_{2} \beta \gamma \delta$ (Popot and Changeux, 1984). During muscle fiber development, the $\gamma$ subunit is replaced by an $\varepsilon$ subunit, which results in a change in the receptor's ion channel properties (Mishina et al., 1986; $\mathrm{Gu}$ and Hall, 1988). In addition to this subunit switch, the distribution of the receptor along the muscle fibers surface changes dramatically during synaptogenesis (Bevan and Steinbach, 1977; Frank and Fischbach, 1979; Anderson et al., 1977). In adult skeletal muscle the $n A C h R$ is found almost exclusively under the nerve terminal (Fertuck and Salpeter, 1974). However, either prior to muscle innervation or after denervation of adult skeletal muscle, the receptor is found throughout the muscle fiber surface (Bevan and Steinbach, 1977; Fambrough, 1974). The molecular mechanisms responsible for this distribution are not known. This paper deals with the role nAChR RNA distribution may play in regulating the location of receptors on innervated and denervated muscle fibers.

The clustering of receptors beneath the nerve terminal during neuromuscular junction development is a combination of the redistribution of preexisting receptors and the synthesis of new molecules (Anderson and Cohen, 1977; Ziskind-Conhaim et al., 1984; Role et al., 1985). The mechanism by which recepturs move to the endplate is not clear, but likely involves interaction with cytoskeletal, membrane, and basal lamina components (Fallon et al., 1985; Burden et al., 1983; Froehner, 1986). In addition, newly synthesized nAChRs may be targeted for the endplate by the Golgi apparatus (Bursztain and Fischbach, 1984). Besides these posttranslational mechanisms, it is likely that transcription of the receptor genes also plays a role in determining the distribution of $n A C h R s$ along the muscle fibers surface. Muscle activity suppresses expression of extrajunctional receptors by decreasing the level of RNA encoding these molecules (Goldman et al., 1988). Concentration of receptors at the endplate may result from a nonuniform distribution of nAChR RNA in adult skeletal muscle (Merlie and Sanes, 1985; Fontaine et al., 1988).

Skeletal muscle fibers are multinucleated. A small number of nuclei out of the total are found under the endplate. These nuclei are morphologically distinct from those found in extrajunctional regions of the muscle fiber (Couteaux, 1973). Perhaps this morphological distinction reflects a specialization of these nuclei. Endplate-associated nuclei may regulate expression of molecules specific to the synapse. Therefore, the pattern of gene expression in these endplate-associated nuclei would be different from that in extrajunctional nuclei. If this were true, one would predict that $n A C h R$ genes would be expressed selectively in those nuclei associated with the endplate in an adult innervated muscle fiber. Consistent with this prediction is the observation that when rat diaphragm muscle is cut into endplatecontaining and non-endplate-containing thirds, RNA blots showed higher levels of $\alpha$ and $\delta$ subunit encoding RNA in those muscle thirds containing endplates compared with those lacking endplates (Merlie and Sanes, 1985). Recently the high resolution technique of in situ hybridization was used to map $\mathrm{n} \wedge \mathrm{ChR} \alpha$ subunit RNA in young chicken muscle fibers (Fontaine et al., 1988). This study revealed the $\alpha$ subunit RNA to be concentrated beneath the neuromuscular junction. When these muscles were denervated and examined 4 days later, an increase in the level of hybridizing $\alpha$ subunit RNA was observed with a random distribution throughout the muscle fibers surface.

This latter result is interesting in light of recent evidence that a gradient of extrajunctional receptors exists early after denervation (Levitt-Gilmour and Salpeter, 1986; Salpeter et al., 1988). Using $\alpha$-bungarotoxin and electron microscopy, a spatial gradient of extrajunc- 
tional nAChRs was observed, with highest concentrations found near the endplate. This gradient of receptors in denervated muscle may also be a result of a nonuniform distribution of $n A C h R$ RNA within the muscle fiber.

In this paper we address the issue of nAChR RNA distribution in innervated and denervated rat soleus muscle. Since probes for the rat muscle $\mathrm{nAChR}$ did not exist, we isolated cDNAs encoding receptor subunits from a rat skeletal muscle cDNA library. The technique of in situ hybridization was used to map $\boldsymbol{\alpha}, \boldsymbol{\beta}, \boldsymbol{\gamma}$, and $\delta$ subunit RNAs in innervated and denervated muscle fibers. In addition, RNA was isolated from endplate-containing and non-endplate-containing thirds of soleus muscle and used in RNAase protection assays to determine the level of $\alpha$ subunit message in these regions of the muscle fiber. These experiments showed that RNAs encoding the $\alpha$, $\boldsymbol{\beta}$, and $\delta$ subunits of the $n A C h R$ are localized beneath the endplate in innervaled muscle and that after muscle denervation, a nonuniform distribution of $\alpha, \beta, \gamma$, and $\delta$ subunit RNAs exists, with highest concentrations found in the extrajunctional regions near endplates.

\section{Results}

\section{Isolation and Characterization of cDNAs Encoding} the $\alpha, \beta, \gamma$, and $\delta$ Subunits

Probes for identifying rat muscle nAChR RNAs were derived from $\lambda \mathrm{gt} 11 \mathrm{cDNA}$ libraries prepared with either innervated or denervated rat muscle poly $(A)^{+}$RNA. Rat muscle nAChR cDNAs were characterized by DNA sequence, $\mathrm{S} 1$ nuclease protection of $\mathrm{mRNA}$, and restriction enzyme digestion. DNA sequence analysis identified cDNAs encoding the $\alpha, \beta, \gamma$, and $\delta$ subunits (data not shown). S1 nuclease protection experiments were performed to confirm that these cDNAs faithfully represented their corresponding RNAs (Figure 1). The results of these analyses are summarized below.

\section{a Subunit CDNA (RIA21)}

RIA21 is approximately 1800 nucleotides long. Its DNA sequence begins at nucleotide -18 and extends into the 3 ' untranslated region when compared with the mouse a subunit cDNA (Boulter et al., 1985). This clone codes for a mature $\alpha$ subunit, including 6 amino acids of the leader peptide. Hybridization of antisense $\alpha$ subunit DNA with innervated or denervated rat muscle RNA shows complete protection of the cDNA by the mRNA (Figure 1). In the denervated lane of Figure 1, two protected bands, differing by approximately 100 nucleotides, were detected. These two bands probably result from the use of alternative polyadenylation signal sequences, as was shown for the mouse $\alpha$ subunit RNA (Goldman et al., 1985). The level of expression of $\alpha$ subunit RNA in these muscles is consistent with previously published reports (Goldman et al., 1988).

\section{$\beta$ Subunit CDNAs (RIB28 and RIB33)}

RIB28 is approximately 1760 nucleotides long. Compared with the mouse $\beta$ subunit CDNA, RIB2 8 begins at nucleotide -66 and extends into the 3 ' untranslated region (Buonanno et al., 1986). This clone codes for the mature $\beta$ subunit and most of the leader peptide. It lacks 5 untranslated sequences and those coding for the initiator methionine. DNA sequence analysis has determined that RIB28 contains 9 additional nucleotides coding for 3 extra amino acids found between residues 43 and 44 of the mouse $\beta$ subunit protein (Goldman and Tamai, 1989). We have also isolated another $\beta$ subunit

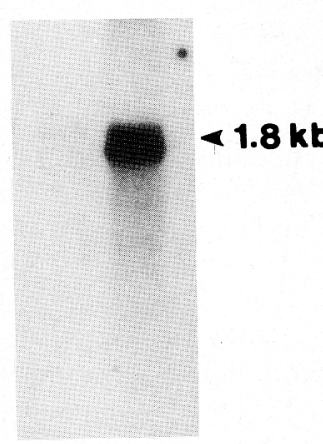

alpha

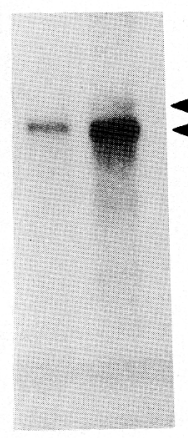

beta

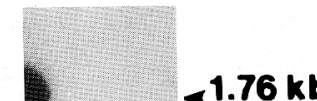

$\$ 1.66$

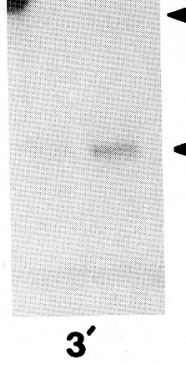

3

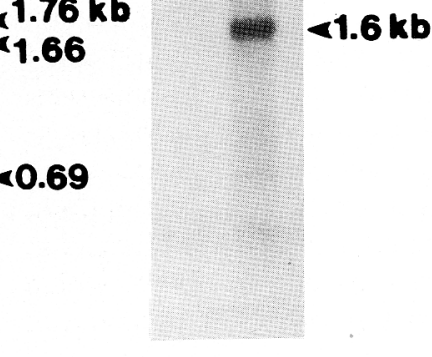

gam ma

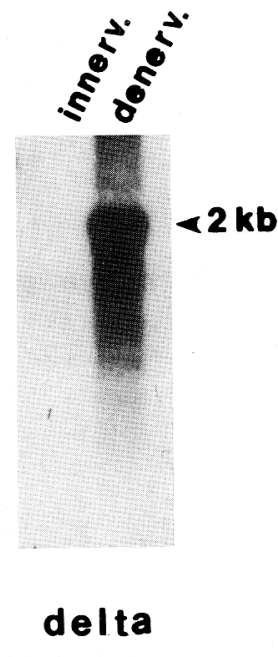

Figure 1. S1 Nuclease Analysis of Rat Muscle mRNAs Complementary to cDNAs Encoding Rat Muscle nAChR Subunits

$\mathrm{Gel}$ profile of $\mathrm{S} 1$ nuclease protected molecules generated by $\mathrm{SI}$ nuclease digestion of heteroduplexes formed between innervated or 5 day denervated rat soleus muscle mRNA $(5 \mu \mathrm{g})$ and $\mathrm{M} 13$ subclones harboring either the $\alpha$ subunit cDNA (RIA21), the $\beta$ subunit cDNA (RIB28), the 3690 nucleotides of the RIB28 cDNA the $\gamma$ subunit CDNA (RIG13-1), or the $\delta$ subunit cDNA (RID3) in the antisense orientation. The first lane for each blot is protection of innervated muscle $m R N A$; the second lane is protection of denervated muscle mRNA. The length of protected fragments was determined by comparing their mobility with DNA standards (1 kb ladder; BRL) and the mobility of 51 nuclease-resistant hybrids formed by hybridizing the sense and antisense strands of the nAChR subunit CDNAs. Radiolabeled probes were $1 \times 10^{3}$ to $4 \times 10^{B} \mathrm{cpm} / \mu \mathrm{g}$, and blots were exposed to X-ray film overnight at $-80^{\circ} \mathrm{C}$ with an intensifying screen. 
CDNA (RIB33) that is identical to RIB28, except it lacks the 9 bases found between residues 43 and 44 of RIB28 (Goldman and Tamai, 1989). Hybridization of antisense RIB28 DNA with RNA isolated from innervated or denervated rat muscle, followed by $\mathrm{S} 1$ nuclease digestion, resulted in the identification of two protected molecules (Figure 1): a low abundance RNA, corresponding to complete protection of the clone $(1.76 \mathrm{~kb})$, and a more abundant RNA that resulted in protection of approximately $1.6 \mathrm{~kb}$ of RIB28. DNA sequence analysis and S1 nuclease protection assays with the $3^{\prime}$ end of RIB28 are consistent with these two RNAs representing clones RIB28 and RIB33, which differ by 9 nucleotides in their $5^{\prime}$ coding sequence (Goldman and Tamai, 1989).

$\gamma$ Subunit CDNA (RIG13-1)

RIG 13-1 is about 1600 nucleotides long. Compared with the mouse $\gamma$ subunit cDNA (Boulter et al., 1986), RIG131 begins at nucleotide 90 and extends into the $3^{\prime}$ untranslated region. Therefore, RIG13-1 codes for a $\gamma$ subunit beginning at amino acid 31 of the mature protein. Hybridization of antisense RIG13-1 to RNA isolated from either innervated or denervated rat muscle, followed by digestion with $\mathrm{S} 1$ nuclease, showed complete protection of RIG13-1 by an abundant RNA expressed in denervated muscle (Figure 1).

\section{$\delta$ Subunit CDNA (RID3)}

RID3 is about 2500 nucleotides long. DNA sequence analysis indicates that this clone begins at residue 64 of the mouse $\delta$ subunit cDNA (LaPolla et al., 1984) and extends into the $3^{\prime}$ untranslated region. Hybridization of RID3 antisense DNA with RNA isolated from denervated muscle, followed by $S 1$ nuclease digestion, resulted in protection of a $2 \mathrm{~kb}$ piece of RID3 (Figure 1). Based on $\mathrm{S1}$ nuclease protection experiments using the 3 ' end of the clone and DNA sequence analysis, we have determined that $500 \mathrm{bp}$ at the extreme 3 ' end of the clone are not part of the $\delta$ subunit RNA (data not shown). Therefore, an EcoRI/Pstl subclone of RID3 (RIDR1/Pstl.4) containing $1.4 \mathrm{~kb}$ of $5^{\prime}$ coding sequence was created.

The lack of a detectable signal in $S 1$ nuclease experiments using innervated muscle RNA and either the $\alpha, \gamma$, or $\delta$ subunit cDNAs is due to the low level of expression of these RNAs in this muscle. These results are consistent with previous reports using Northern blot analysis to assay for the levels of these RNAs (Evans et al., 1987; Goldman et al., 1988). Controls for S1 nuclease protection experiments included hybridization without mRNA, which resulted in no protected bands, and hybridization of sense and antisense strands of the clones, which resulted in complete protection of the clone (data not shown).

Distribution of $\alpha, \beta, \gamma$, and $\delta$ Subunit RNAs in Innervated and Denervated Rat Soleus Muscle Fibers Acetylcholine receptors are localized to the endplates of innervated muscle fibers. After denervation, receptors are found throughout the muscle fiber surface, with highest concentrations occurring in extrajunctional regions nearest the endplate (Salpeter et al., 1988). Is this distribution of $\mathrm{nAChR}$ protein reflected in the distribu- tion of its RNAs? To address this issue it was necessary to identify nAChR RNAs in muscle fibers and correlate their distribution with that of endplates. For this analysis, 3-week-old rat soleus muscles were denervated for 0,6 , 18,44 , and $66 \mathrm{hr}$. Muscles were then isolated and prepared for endplate staining and in situ hybridization.

Figure 2 shows the results obtained when innervated and $66 \mathrm{hr}$ denervated muscle was subjected to this analysis. Columns labeled $\alpha$ Btx show fluorescent $\alpha$-bungarotoxin staining of endplates; columns labeled RNA show the distribution of $n A C h R$ RNA in these same muscle fibers. In innervated muscle the $\alpha, \beta$, and $\delta$ subunit RNAs were found to be concentrated beneath endplates, whereas no $\gamma$ subunit RNA could be detected. The experiment was repeated on two additional animals, one about 14 days old and the second a mature adult. Although the endplate staining and detection of RNA appeared to be more robust in the younger animals, there were no significant differences in our results. A minimum of 20 endplates were examined for each nAChR RNA probe used, and of these endplates, a minimum of $70 \%$ showed colocalization of $\alpha, \beta$, and $\delta$ subunit RNAs. The number of grains in these endplate regions was generally greater than 50 -fold above that found in extrajunctional regions of the muscle fiber. The concentration of grains was generally higher around endplate nuclei than throughout the surrounding cytoplasm.

If one repeats this experiment using soleus muscle that was denervated for 6 or $18 \mathrm{hr}$, profiles of nAChR RNA distribution look identical to those observed in innervated muscle (data not shown). However, after $66 \mathrm{hr}$ of muscle denervation, a large increase in the levels of $\alpha, \beta, \gamma$, and $\delta$ subunit RNAs is observed (Figure 2). The hybridization of receptor RNAs to the probes is generally found to be clustered around nuclei. In addition, this RNA is concentrated in extrajunctional regions of the muscle near endplates (see next section). We have not noticed a significant difference in the level of $n A C h R$ RNA associated with junctional versus extrajunctional nuclei near the endplate in the denervated muscle fiber.

Controls for the in situ hybridization included the use of a sense strand probe and an RNAase treatment prior to hybridization. Both these controls showed no hybridization above background (data not shown). As an additional control, we hybridized innervated and $66 \mathrm{hr}$ denervated muscle sections with a $\left(\mathrm{Na}^{+}, \mathrm{K}^{+}\right)$ATPase $\alpha 1$ subunit probe (Figure 3). The level of RNA encoding this subunit does not change significantly during muscle development (Orlowski and Lingrel, 1988). Consistent with these findings, we observed no significant difference in the level of expression of this RNA in innervated compared with denervated rat soleus muscle (Figure 3 ). Therefore, the differences we detected for nAChR RNAs in these muscles were specific.

\section{A Nonuniform Distribution of nAChR RNA following Muscle Denervation}

At early times following muscle denervation, a gradient of extrajunctional nAChRs appears, with highest concentrations occurring near the endplate (Levilt-Gilmour 

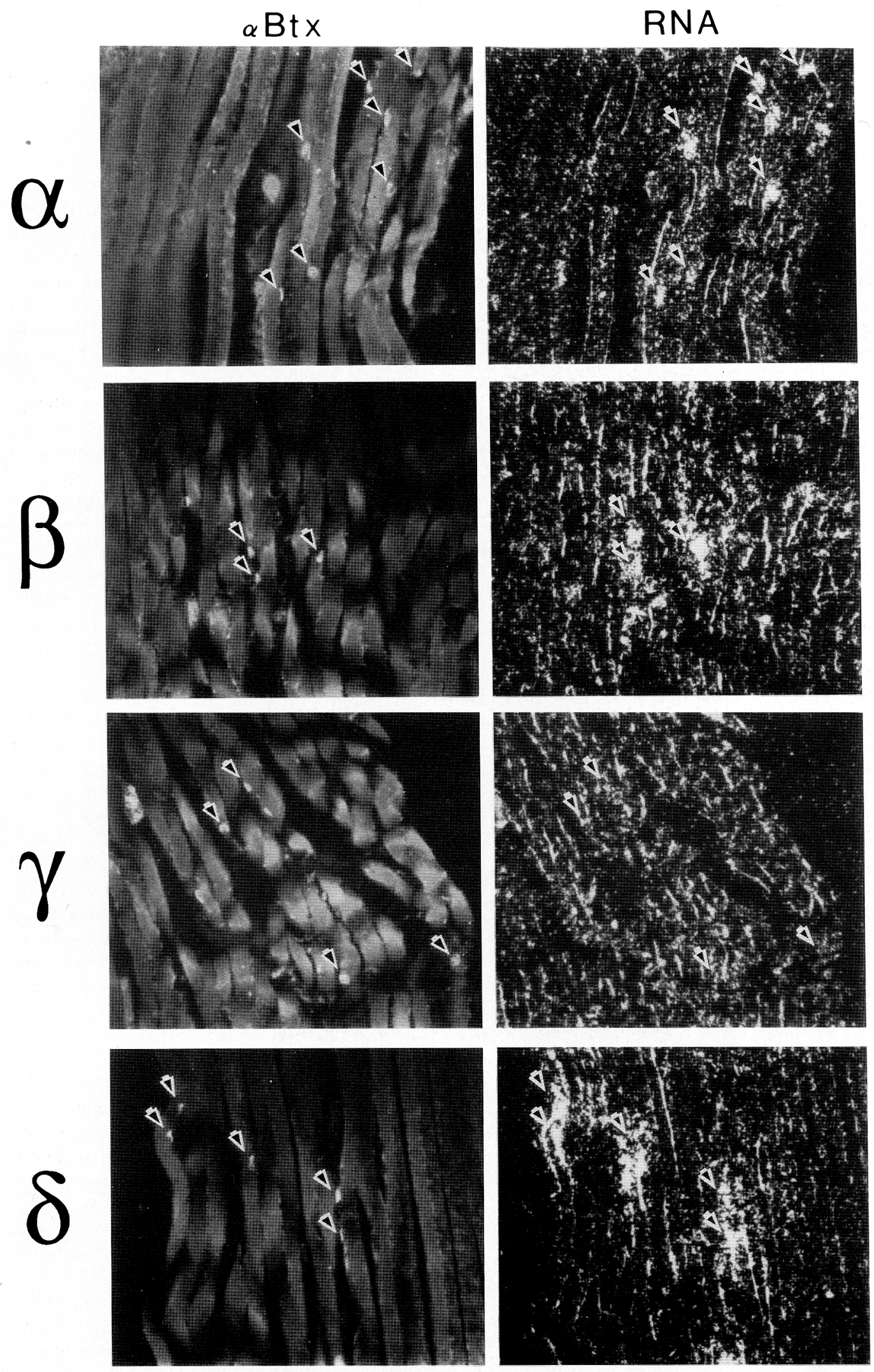

\section{Innervated}

Figure 2. Distribution of nAChR RNA and Endplates in Innervated and Denervated Rat Soleus Muscles

The distribution of endplates and nAChR RNA was determined in innervated and $66 \mathrm{hr}$ denervated soleus muscles. Columns labeled $\alpha B t x$ are photomicrographs, using fluorescence optics, of endplates stained with FITC-a-bungarotoxin. Columns labeled RNA are photomicrographs, using a dark-field condenser, of these same muscle sections after in situ hybridization to identify nAChR RNA. RNA was visualized by a 4 week exposure of the slides after dipping in liquid emulsion. 

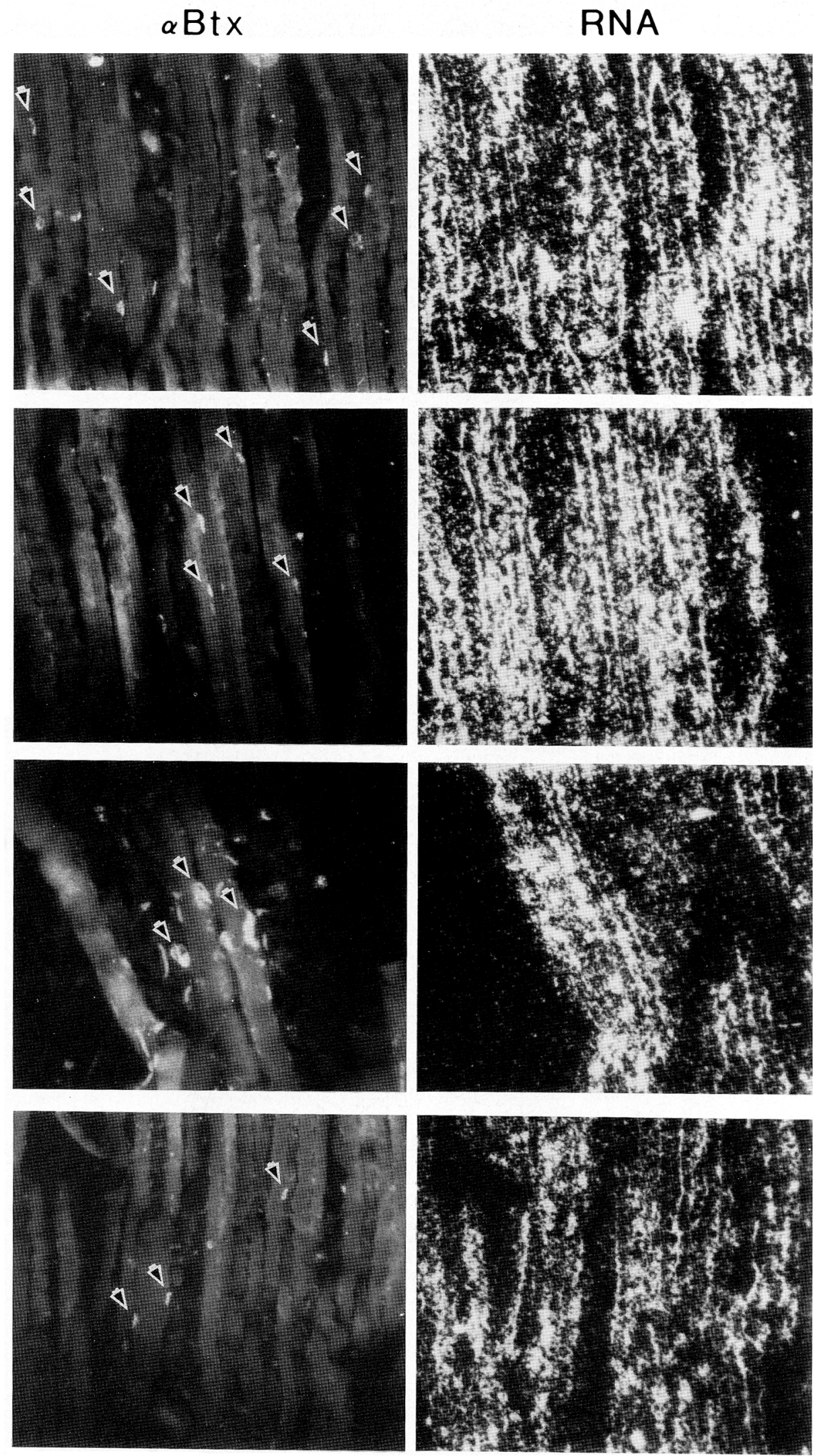

Denervated 


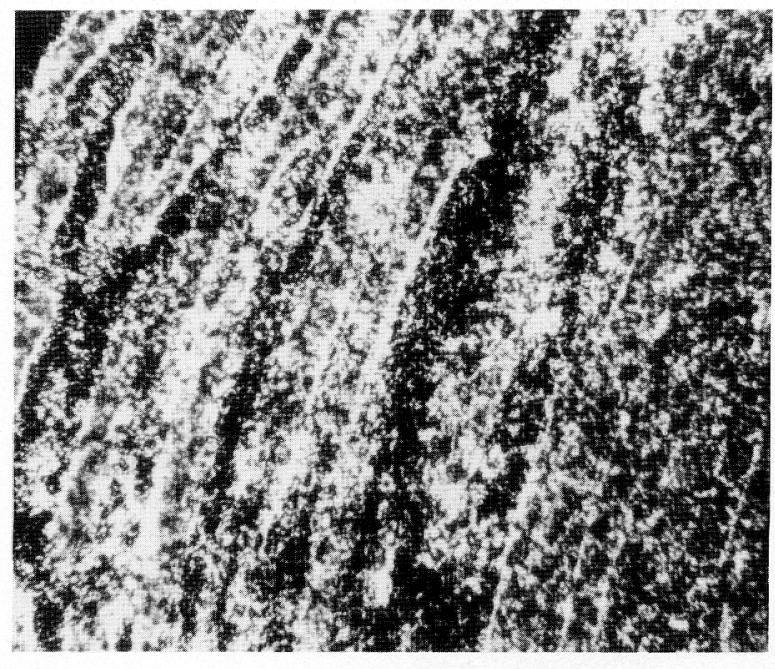

Innervated

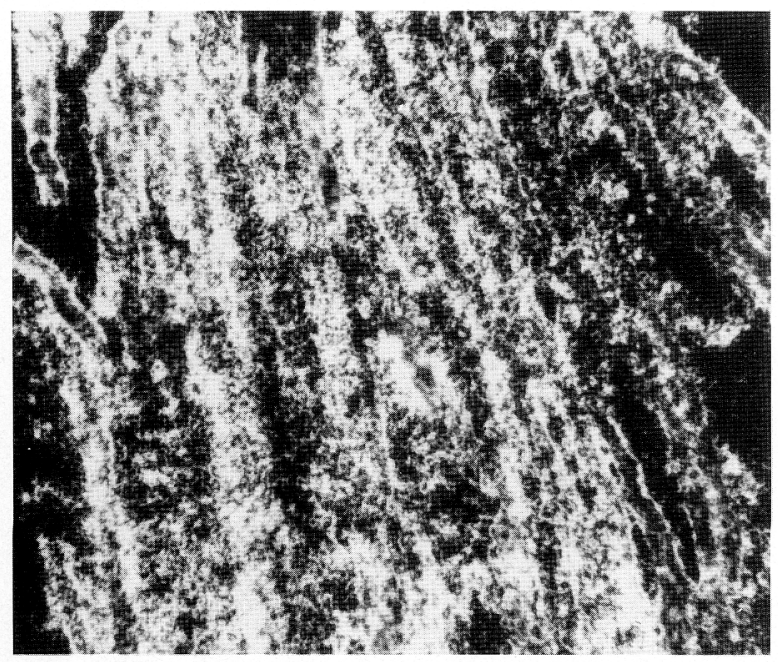

Denervated

Figure 3. RNA Encoding the $\alpha 1$ Subunit of the $\left(\mathrm{Na}^{+}, \mathrm{K}^{+}\right)$ATPase Is Distributed throughout Innervated and Denervated Rat Soleus Muscle Innervated and $66 \mathrm{hr}$ denervated rat soleus muscle sections were hybridized with a $\left(\mathrm{Na}^{+}, \mathrm{K}^{+}\right)$ATPase $\alpha 1$ subunit antisense RNA probe in situ. After the in situ hybridization procedure, slides were dipped in liquid emulsion and exposed for 4 days. Dark-field photomicrographs were taken with a $20 \times$ objective.

and Salpeter, 1986; Salpeter et al., 1988). This pattern may result in part from the distribution of nAChR RNA. Our in situ hybridization data indicated that on $66 \mathrm{hr}$ denervated soleus muscles, nAChR RNA levels are highest in extrajunctional regions of the fiber near the endplate. We examined the distribution of $\boldsymbol{\alpha}, \boldsymbol{\beta}, \boldsymbol{\gamma}$, and $\delta$ subunit RNAs in 11 day denervated soleus muscle using in situ hybridization (Figure 4). To obtain a low resolution profile of the distribution of these RNAs along the muscle, we visualized the hybridization profile by contact autoradiography and quantitated the data by densitometry. This analysis showed all four subunit RNAs to be concentrated in a region of the muscle shown, by FITC- $\alpha$-bungarotoxin staining, to be enriched for endplates (Figure 4). As a control (Figure 4, lane C), the distribution of RNA encoding the $\left(\mathrm{Na}^{+}, \mathrm{K}^{+}\right)$ATPase $\alpha$ l subunit is shown to be uniformly distributed throughout the fiber.

To determine whether the distribution of nAChR RNA is reflected in the distribution of muscle nuclei, we counted nuclei in junctional and extrajunctional regions of the fiber. This analysis showed no significant differences in the number of nuclei between these regions of the muscle (Figure 4).

The earliest time following muscle denervation that we have been able to detect an increase in $\alpha$ subunit RNA is approximately $30-40 \mathrm{hr}$. Therefore, we compared the distribution of $\alpha$ subunit RNA in innervated, 36 denervated and 4 day denervated soleus muscle by in situ hybridization. Contact autoradiography of these muscle sections showed a significant increase in a subunit RNA at $36 \mathrm{hr}$ postdenervation (Figure 5). This
RNA is concentrated in the central region of the muscle fiber where endplates are found. At 4 days postdenervation, a large increase in $\alpha$ subunit RNA is observed, but its levels are still highest in the endplate-containing central third of the muscle (Figure 5). Although our results with the $\left(\mathrm{Na}^{+}, \mathrm{K}^{+}\right)$ATPase $\alpha 1$ RNA indicate that this localization is nol a general phenomenom found for all muscle RNAs, we confirmed this result using RNAase protection assays.

For this analysis, denervated rat soleus muscles were divided into thirds. The middle third of these muscles is enriched for endplates the outer two-thirds generally lack endplates. Total RNA was isolated from these portions of the soleus muscle and hybridized with radiolabeled $\alpha$ subunit probe. The probe was prepared from a recombinant plasmid (pSP65) harboring RIA21 in an antisense orientation in relation to the SP6 promoter. After linearization of this construct with Accl, a ${ }^{32} \mathrm{P}$-labeled antisense RNA probe was synthesized by run-off transcription. Accl restricts RIA21 about 344 nucleotides from the 3' end of the clone. After hybridization of the muscle RNA with this probe, RNAase was added, and those molecules surviving digestion were fractionated on a $4 \%$ acrylamide, $8 \mathrm{M}$ urea gel. Hybrids were visualized by autoradiography. Consistent with the in situ hybridization experiments, a gradient of $\alpha$ subunit RNA was detected in 2 and 4 day denervated muscle, with highest concentrations occurring in the endplate-enriched middle third (Figure 6). When this experiment was performed with innervated muscle RNA, a much reduced junctional signal was detected (data not shown; however, see Figure 5). As a control we used a randorn 

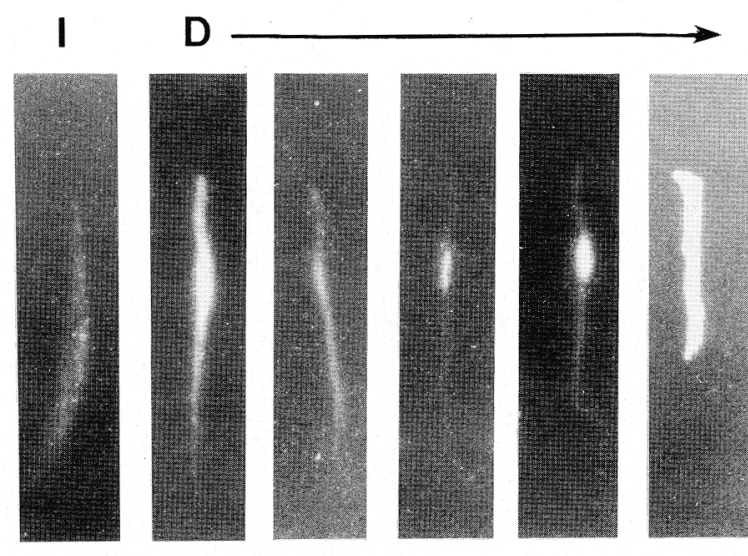

$$
\alpha
$$

\begin{abstract}
$\alpha$
\end{abstract}

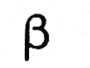

$\gamma$

$\delta$

C
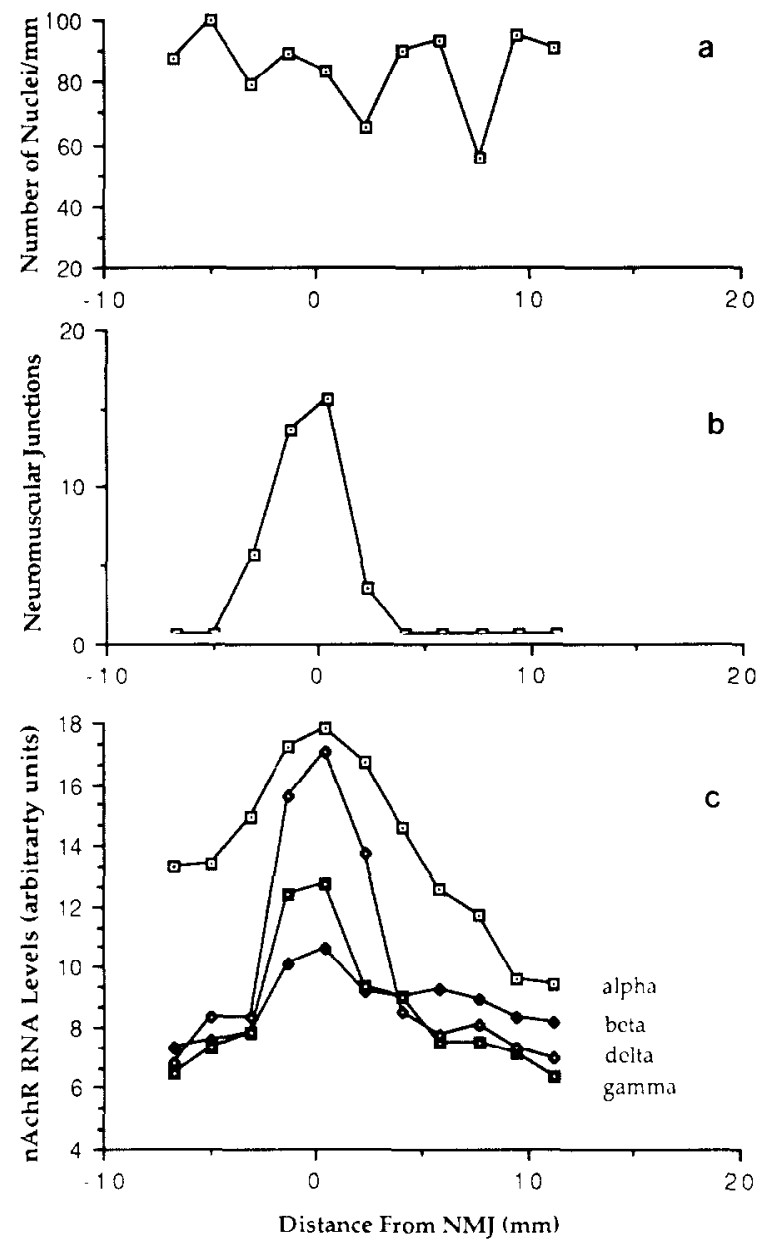

Figure 4. A Nonuniform Distribution of nAChR RNA in Denervated Rat Soleus Muscle

(Top) Contact autoradiography showing innervated (I) or 11 day denervated $(D)$ rat soleus muscles after hybridization with $\alpha, \beta, \gamma$, or $\delta$ subunit RNA probes. Lane $C$ is a control using 4 day denervated soleus muscle hybridized with a $\left(\mathrm{Na}^{+}, \mathrm{K}^{+}\right)$ATPase $\alpha$ l subunit RNA probe. Autoradiographic exposures were for 4 days.

(Bottom) Quantitation of nuclei (a), neuromuscular junctions (b), and nAChR RNA (c), levels in denervated muscle sections shown in the above autoradiogram. A serial section of the muscle hybrid.

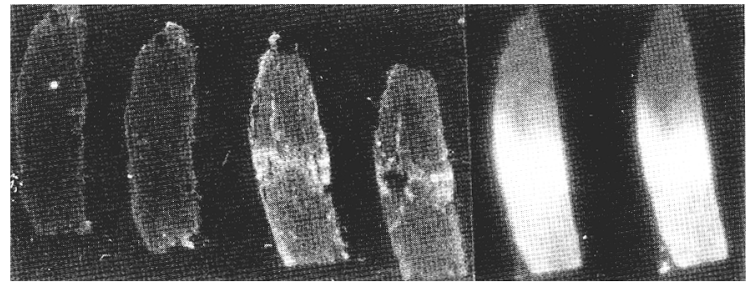

$\mathrm{Ohr}$ $36 \mathrm{hrs}$

4 days

Figure 5. Time Course of $\boldsymbol{\alpha}$ Subunit RNA Distribution in Denervated Rat Soleus Muscle

Duplicate longitudinal sections of $0,36 \mathrm{hr}$, and 4 day denervated rat soleus muscles were hybridized in situ with an ${ }^{15}$ S-labeled $\alpha$ subunit probe. Hybridization was visualized by contact autoradiog. raphy for 4 days.

clone isolated from our rat muscle CDNA library that identifies an RNA not regulated by muscle denervation (Figure 6, lane C).

\section{Discussion}

The level of expression and the distribution of $n A C h R s$ along the muscle fiber surface changes both during muscle development and after denervation of adult muscle (reviewed in Schuetze and Role, 1987). The mechanism by which the nerve exerts its effect on receptor levels and distribution is not known. It is clear that muscle activity induced by the neuron regulates extrajunctional $\mathrm{nAChR}$ levels by regulating the level of RNA encoding these receptors (Goldman et al., 1988). If muscle activity suppresses expression of extrajunctional nAChRs, why does it not suppress expression of junctional receptors? Perhaps muscle activity influences $n A C h R$ expression differently in junctional and extrajunctional regions of the muscle fiber.

Recently it has been shown that the distribution of $\alpha$ subunit RNA in innervated 15-day-old chick skeletal muscle is localized beneath the endplate (Fontaine et al., 1988). In rat diaphragm muscle, RNA blot analysis was used to show that the $\alpha$ and $\delta$ subunit RNAs are concentrated in the synapse-containing middle third of that muscle (Merlie and Sanes, 1985). This nonuniform distribution of $n A C h R$ RNA might arise from selective $n A C h R$ gene expression in those nuclei found beneath the endplate. Alternatively, receptor RNA may be stabilized at the endplate or transported there. We report in this paper that $\boldsymbol{\alpha}, \boldsymbol{\beta}$, and $\delta$ subunit RNAs are found only under

ized with the a subunit probe labovel was stained for endplates with FITC- $\alpha$-bungarotoxin. Nuclei were visualized by staining with hematoxylin, and their number was determined for a distance of I $\mathrm{mm}$ at various points along individual fibers. Distance on the horizontal axis is recorded in millimeters away from the highest density of endplates $(0 \mathrm{~mm})$. The muscle section was approximately $18 \mathrm{~mm}$ in length. 


\section{J EJ J EJ

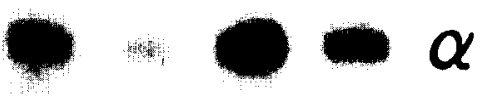

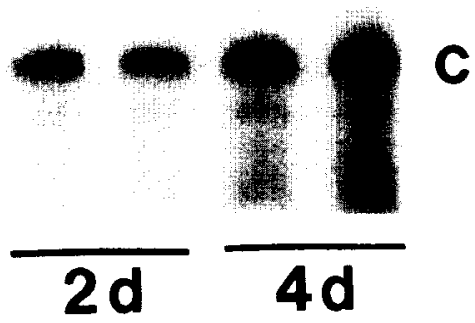

Figure 6. a Subunit RNA Increases More in Endplate-Containing Thirds versus Extrajunctional Thirds of Denervated Rat Soleus Muscle

Gel profile showing levels of $\alpha$ subunit RNA in junctional versus extrajunctional thirds of denervated rat soleus mucle. Rat lower hindlimb muscles were denervated for 2 and 4 days. Soleus muscles were then dissected out and divided into junctional $(J)$ and extrajunctional (EJ) thirds. Ten micrograms of RNA isolated from these muscle thirds, was hybridiced with a ${ }^{32} \mathrm{P}$-labeled $\alpha$ suburit RNA probe (see Experimental Procedures). As a control (C), a probe was made from a clone, isolated from the rat muscle cDNA library, that represented an RNA not regulated by muscle denervation. Following hybridization, RNAase A was added, and protected duplexes were fractionated on a denaturing acrylamide gel. The dried gel was exposed to $X$-ray film overnight at $-80^{\circ} \mathrm{C}$ with an intensifying screen.

the neuromuscular junction in innervated rat soleus muscle (Figure 2). We were unable to detect any $\gamma$ subunit RNA in these muscles. This is expected, since there is a subunit switch during development by which the $\gamma$ subunit, expressed early in development, is replaced by the $\varepsilon$ subunit. Since we do not have a probe for the $\varepsilon$ subunit RNA, we were not able to study its distribution.

The mechanism by which $\mathrm{nAChR} \boldsymbol{\alpha}, \boldsymbol{\beta}$, and $\delta$ subunit RNAs are concentrated beneath the endplates of innervated muscle is not known. If in innervated muscle all nuclei were expressing $n A C h R$ genes and RNA was transported to the endplate, one might expect a gradient of RNA to be observed. This was not the case; we found nAChR RNA to be concentrated beneath the endplate and not detectable in extrajunctional regions close to the endplate. A second possibility is that the endplate environment results in stabilization of nAChR RNA. Alternatively, it is possible that endplate nuclei selectively express their $n A C h R$ genes, whereas extrajunctional nuclei do not. These latter two hypotheses imply that the innervating neuron contributes to an environment at the endplate which locally influences either nAChR RNA stability or gene transcription.

The idea of the nerve exerting a trophic influence on nAChR RNA expression is supported by the identification of neurotrophic molecules that increase $\alpha$ subunit RNA levels in cultured muscle cells. One candidate for this trophic activity is calcitonin gene-related peptide (New and Mudge, 1986). This molecule is found in motoneurons and has been shown to increase $n A C h R$ protein and RNA levels in cultured chick muscle cells (Fontaine et al., 1987). Another candidate is ARIA, a gly coprotein purified from chick brain that selectively increases $\boldsymbol{\alpha}$ subunit RNA levels in myotubes (Harris et al., 1989). Whether these molecules serve to regulate $n A C h R$ gene expression in vivo is not yet clear.

After denervating rat soleus muscles, we observed a nonuniform distribution of $\mathrm{nAChR}$ RNA expression (Figures 4,5 , and 6 ). The highest levels of $\alpha, \beta, \gamma$, and $\delta$ subunit RNAs were found in extrajunctional regions of the muscle near the endplate. This result is different from the random distribution of $\alpha$ subunit RNA found in denervated chick muscle (Fontaine et al., 1988). The reason for this difference between rat and chick is not known. It may be a result of a species or muscle-type difference. Our results in rat are consistent with the observation by Levitt-Gilmour and Salpeter (1986) that a gradient of $n A C h R$ protein exists at early times following muscle denervation. These investigators showed, using $\alpha$-bungarotoxin and electron microscopy, that a spatial gradient of extrajunctional nAChRs exist, with highest concentrations occurring near the endplate in denervated muscle. This is likely to be due, at least in part, to the distribution of nAChR RNA in denervated muscle.

The identification of a nonuniform distribution of nAChR RNA in denervated muscle was not expected. Preliminary experiments with muscle cells in culture indicate that this distribution is dependent on prior innervation of the muscle. Thus, it is possible that interactions between nerve and muscle result in a changed environment in junctional and extrajunctional regions near the endplate. This influence of the nerve would be largest at the endplate and would diminish as one moves away into extrajunctional regions. In an active muscle, in which extrajunctional $n A C h R$ gene expression is repressed, this environment has little influence beyond the endplate, and therefore one observes local expression of nAC.hR RNA. However, upon denervation, one observes two superimposed RNA distributions: a uniform one along the muscle fiber due to muscle inactivity and a steep gradient of RNA decreasing away from endplates due to the prior influence of innervation.

\section{Experimental Procedures}

\section{RNA Isolation}

RNA was isolated using the guanidinium isothiocyanate procedure as described previously (Chirgwin et al., 1979; Goldman et al. 19851. Poly (A) ${ }^{+}$RNA was selected tor by chromatography over an oligo(dT)-cellulose column (Aviv and Leder, 1972).

Construction and Screening of cDNA Library

CDNA libraries were constructed using rat poly $(A)^{+}$RNA isolated 
from adult innervated or denervated rat skeletal muscle. The method of Gubler and Hoffman (1983) was used to prepare sizefractionated double-stranded cDNA. The cDNA was ligated to phosphorylated EcoRI linkers and was then cloned into the EcoRI site of bacteriophage $\lambda g t 11$ (Huynh ct al., 1985). Approximately 0.5 $\times 10^{\mathrm{t}}$ plaques were screened from this library with radiolabeled CDNA encoding the BC $3 \mathrm{H} 1$ mouse muscle $\mathrm{NAChR} \alpha, \beta, \gamma$, or $\delta$ subunits (Boulter et al., 1985, 1986; LaPolla et al., 1984; Evans et al. 1987).

\section{DNA Sequence Determination}

cDNAs were subcloned into the $\mathrm{M} 13$ bacteriophage vectors mpl8 and mp19. DNA sequence was determined using the dideoxynucleotide chain termination method (Sanger et al., 1977). Unidirec tional deletions were generated using the method of Dale et al. (1985).

\section{S1 Nuclease Protection Assay}

$\$ 1$ Nuclease digestions of heteroduplexes formed between poly $(A)^{+}$RNA and $M 13$ subclones of the rat $\alpha, \beta, \gamma$, or $\delta$ subunit cDNAs were carried out as previously described (Goldman et al. 1985). Those hybrids surviving $S 1$ nuclease digestion were analyzed by electrophoresis through a $2.2 \mathrm{M}$ formaldehyde, $1.4 \%$ agarose gel. The size-fractionated heteroduplexes were transferred to a Gene Screen Plus membrane and detected by hybridization to nick-translated radiolabeled rat nAChR subunit cDNAs.

\section{RNAase A Protection Assay}

Rat soleus muscles were divided into junctional- and extrajunctional-containing thirds. Total RNA was isolated trom these muscles and hybridized with a 'P-labeled antisense a subunit RNA probe. This probe was prepared by run-off transcription of a linearized p) 965 vector in which RIA21 was subcloned. The recombinant vector was linearized with Accl, which restricts RIA21 about 344 mucleotides from its 3 end. Hybridization conditions were in a 0.03 $\mathrm{ml}$ volume containing $50 \%$ formamide, $40 \mathrm{mM}$ PIPES $(\mathrm{pH} 6.7), 0.4$ $\mathrm{m} \mathrm{NaCl}$, and $1 \mathrm{mMEDTA}\left(\mathrm{pH} 8.0\right.$ ) at $45^{\circ} \mathrm{C}$ for $16 \mathrm{hr}$. Following hybridization, $0.3 \mathrm{ml}$ of RNAase digestion buffer containing 0.04 $\mathrm{mg} / \mathrm{ml}$ RNAase $\mathrm{A}$ in $10 \mathrm{mM}$ Tris-HCl $(\mathrm{pH} 7.5), 5 \mathrm{mM}$ EDTA, $0.3 \mathrm{M}$ $\mathrm{NaCl}$ was added. The digestion was allowed to proceed for $1 \mathrm{hr}$ at $30^{\circ} \mathrm{C}$ and was terminated by the addition of $0.02 \mathrm{ml}$ of $10 \%$ SDS and $0.05 \mathrm{mg}$ of proteinase $\mathrm{K}$. Incubation was continued for an additional $15 \mathrm{~min}$ at $37^{\circ} \mathrm{C}$. The samples were then extracted with phenol-chlorotorm and precipitated with ethanol. Those hybrids surviving digestion were size-fractionated on a denaturing $5 \%$ acrylamide, $8 \mathrm{M}$ urea gel. Following electrophoresis, the gel was exposed to X-ray film with an intensifying screen at $-80^{\circ} \mathrm{C}$.

\section{Endplate Staining and In Situ Hybridization}

Rat soleus muscles were denervated as described previously iGoldman et al., 1988). While under ether anesthesia, animals were perfused through the heart with $500 \mathrm{ml}$ of $4 \%$ paraformaldehyde, $0.05 \%$ glutaraldehyde in $10 \mathrm{mM}$ sodium phosphate, $145 \mathrm{mM}$ sodium chloride $(\mathrm{pH} 7.4)$. Muscles were postfixed overnight at $4^{\circ} \mathrm{C}$ in the above solution containing $15 \%$ sucrose. I issue was frozen in mounting media and $10 \mu \mathrm{m}$ thick sections were cut on a cryostat. Sections were mounted on polylysine-coated slides and dried at $80^{\circ} \mathrm{C}$ for $10-20 \mathrm{~min}$. Sections were stored at $-20^{\circ} \mathrm{C}$

Prior to staining endplates, sections were placed in PBS $(10 \mathrm{mM}$ sodium phosphate [pH 7.4], $145 \mathrm{mM}$ sodium chloride) for $10 \mathrm{~min}$. immersed in 4\% paraformaldehyde in PBS for $30 \mathrm{~min}$, and washed twice in PBS. Sections were then immersed in PBS containing 1 $\mu \mathrm{g} / \mathrm{ml}$ fluorescein isothiocyanate $\alpha$-bungarotoxin for $30 \mathrm{~min}$, fol. lowed by two $10 \mathrm{~min}$ washes in PBS, dehydrated in alcohol, and allowed to air dry. Endplates were visualized using a Zeiss Axiophot microscope equipped with fluorescein optics. Endplates were recorded by photography and by the coordinates of their position on the slide.

Immediately following the recording of endplates, sections were processed for in situ hybridization as previously described (Cox et al. 1984: Goldman et al., 1986). Hybridization was at $55^{\circ} \mathrm{C}$ overnight using $5 \times 10^{7} \mathrm{cpm}$ of probe per $\mathrm{ml}$. Probes were prepared by run-off transcription of linearized plasmids harboring the subunit-specific cDNAs flanked by the SP6 and T7 promoters. The a subunit RNA probe was prepared from pSP73/RIA950. This vector contains a 950 nucleotide internal Pstl fragment of the rat muscle nAChR a subunit cDNA, RIA21. The $\beta$ subunit RNA probe was prepared from pSP73/RIBR1/Smal. This plasmid harbors the 5' 1200 nucleotide EcoRI-Smal fragment of RIB33. The $\gamma$ subunit probe was prepared from pGEM4/RIG13-1. This plasmid harbors the complete $1.6 \mathrm{~kb} \mathrm{cDNA} \lambda$ insert. The $\delta$ subunit probe was prepared from pSP64RIDR1/Pstl400. This plasmid contains the 5' 1400 nucleotide EcoRI-Pstl fragment of RID3. The majority of sequence in these probes is protein coding. We have determined the specificity of these probes by hybridization to blots containing cDNAs encoding the $\alpha, \beta, \gamma$, and $\delta$ subunits and have found no cross-reactivity using our in situ hybridization conditions (data not shown). Probes were hydrolyzed to an average of 100-200 nucleotides. Posthybridization treatments included a wash at $60^{\circ} \mathrm{C}$ in $50 \%$ formamide, $2 \times$ SSC (0.3 M NaCl, 0.3 M sodium citrate), $50 \mathrm{mM}$ dithiothreitol ( $\mathrm{pH} 7.4$ ) for $20 \mathrm{~min}$, a digestion in RNAase $A(20 \mu \mathrm{g} / \mathrm{ml})$, and a final wash in $0.1 \times$ SSC. Sections were dehydrated in ethanol and dipped in Kodak NTB 2 emulsion. Slides were exposed at $4{ }^{\circ} \mathrm{C}$ tor $4-30$ days, developed, and stained with hematoxylin and eosin $B$.

\section{Acknowledgments}

CDNA libraries were prepared in the laboratories of Drs. Steve Heinemann and Jim Patrick while D. G. was a postdoctoral fellow there. We thank them and Dr. Jim Boulter for help and advice in preparing and screening the libraries. We thank Dr. Jerry Lingrel for providing us with the al $\left(\mathrm{Na}^{+}, \mathrm{K}^{+}\right)$ATPase cDNA, Dr. Virginia Hieber for preparing this DNA for the in situ hybridization experiments, and Kathy Tamai for performing the $S 1$ nuclease protection experiments. We also thank Dr. Zach Hall for critical reading of the manuscript. This work was supported by grants awarded to D. C. from the National Institutes of Health, the Muscular Dystrophy Association of America and the Lucille P. Markev Charitable Trust.

Received March 28, 1989; revised May 18, 1989.

\section{References}

Anderson, M. J., and Cohen, M. W. (1977). Nerve-induced and spontaneous redistribution of acetylcholine receptors on cultured muscle cells. I. Physiol. 268, 757-773.

Anderson, M. J., Cohen, M. W., and Zorychta, E. (1977). Etfects of innervation on the distribution of acetylcholine receptors on cultured muscle cells. J. Physiol. 268, 731-756.

Aviv, H., and Leder. P. (1972). Purification of biologically active globin messenger RNA by chromatography on oligothymidylic acid-cellulose. Proc. Natl. Acad. Sci. USA 69, 1408-1412.

Bevan, 5., and Steinbach, J. H. (1977). The distribution of $\alpha$-bungarotoxin binding sites on mammalian skeletal muscle developing in vivo. 1. Physiol. 267, 195-215

Boulter, J., Luyten, W., Evans, K., Mason. P., Ballivet, M., Goldman, D. Stengelin, S., Martin, G., Heinemann, S., and Patrick, J. (1985). Isolation of a clone coding for the $\alpha$-subunit of a mouse acetylcholine receptor. I. Neurosci. 5, 2545-2552

Boulter, J., Evans, K., Martin, G., Mason. P., Stengelin. S., Goldman D. Heinemann. S., and Patrick, I. (1986). Isolation and sequence or cDNA clones coding for the precursor to the $y$-suburit of mouse muscle nicotinic acetylcholine receptor. I. Neurosci. Res. 16 $37-49$.

Buonanno. A. Mudd, J., Shah, V., and Merlie. I. P. (1986). A universal oligonucleotide probe for acetylcholine recentor genes. I. Biol Chem. 261, 16451-16458

Burden, 5. (1977). Acetylcholine receptors at the neuromuscular junction: developmental changes in receptor turnover. Dev. Biol 61. 79-85.

Burden, S. J., DePalma, R. L., and Gottesman, G. S. (1983). Crosslinking of proteins in acetylcholine receptor-rich membranes: association between the $\beta$ subunit and the $43 \mathrm{kd}$ subsynaptic protein. Cell $35,687-692$ 
Bursztajn, S., and Fischbach, C. D. (1984). Evidence that coated vesicles transport acetylcholine receptors to the surface membrane of chick myotubes. J. Cell Biol. 98, 498-506.

Chirgwin, J. M., Przybyla, A. E., MacDonald, R. J., and Rutter, W. J. (1979). Isolation of biologically active ribonucleic acid from sources enriched in ribonuclease. Biochemistry 18, 5294-5299.

Couteaux, R. (1973). Motor endplate structure. In Structure and Function of Muscle, Vol. 2, C. H. Bourne, ed. (New York: Academic Press, Inc.), pp. 483-530.

Cox, K. H., Deleon, D. V., Angerer, L. M., and Angerer, R. C. (1984). Detection of mRNAs in sea urchin embryos by in situ hybridization using asymmetric RNA probes. Dev. Biol. 101, 485-502.

Dale, R. M. K., McClure, B. A., and Houchins, J. P. (1985). A rapid single-stranded cloning strategy for producing a sequential series of overlapping clones for use in DNA sequencing: applications to se. quencing the corn mitochondrial 18s rDNA. Plasmids 13, 31-40.

Evans, S., Goldman, D., Heinemann, S., and Patrick, J. (1987). Muscle acetylcholine receptor biosynthesis. J. Biol. Chem. 262, 49114916.

Fallon, I. R., Nitkin, R. M., Reist, N. E., Wallace, B. G., and McMahan, U. J. (1985). Acetylcholine receptor-aggregating factor is similar to molecules concentrated at neuromuscular junctions. Nature 315,571574

Fambrough, D. M. (1974). Acetylcholine receptor: revised estimates of extrajunctional receptor density in denervated rat diaphragm. J. Gen. Physiol. 64, 468-472.

Fertuck, H. C., and Salpeter, M. M. (1974). Localization of acetylcholine receptors by ${ }^{125}$ - $\alpha$-bungarotoxin binding at mouse neuromuscular junctions. Proc. Natl. Acad. Sci. USA 71, 1376-1378.

Fontaine, B., Klarsfeld, A., and Changeux, J.-P. (1987). Calcitonin gene-related peptide and muscle activity regulate acetylcholine receptor $\alpha$-subunit mRNA levels by distinct intracellular pathways. J. Cell Biol. 105, 1337-1342.

Fontaine, B., Sassoon, D., Buckingham, M., and Changeux, J.-P. (1988). Detection of the nicotinic acetylcholine receptor $a$-subunit mRNA by in situ hybridization at neuromuscular junctions of 15 day-old chick striated muscles. EMBO J. 7, 603-609.

Frank, E., and Fischbach, C. D. (1979). Early events in neuromuscular junction formation in vitro. Induction of acetylcholine receptor clusters in the postsynaptic membrane and morphology of newly formed synapses. J. Cell Biol. 83, 143-158.

Froehner, S. C. (1986). The role of the postsynaptic cytoskeleton in AchR organization. Trends Neurosci. 9, 37-41.

Goldman, D., and Tamai, K. (1989). Coordinate regulation of RNAs encoding two isoforms of the rat muscle nicotinic acetylcholine receptor B-subunit. Nucl. Acids Res. 17, 3049-3056.

Goldman, D., Boulter, J., Heinemann, S., and Patrick, J. (1985). Muscle denervation increases the levels of two mRNAs coding for the acetylcholine receptor $\alpha$-subunit. J. Neurosci. 5, 2553-2558. Goldman, D., Simmons, D., Swanson, L., Patrick, J., and Heinemann, S. (1986). Mapping brain areas expressing RNA homologous to two different acetylcholine receptor alpha subunit cDNAs. Proc. Natl. Acad. Sci. USA 83, 4076-4080.

Goldman, D., Brenner, H. R., and Heinemann, S. (1988). Acetylcholine receptor $\alpha-, \beta-, \gamma$, and $\delta$-subunit mRNA levels are regulated by muscle activity. Neuron 1, 329-333.

Gu, Y., and Hall, Z. W. (1988). Immunological evidence for a change in subunits of the acetylcholine receptor in developing and denervated rat muscle. Neuron 1, 117-125.

Gubler, U., and Hoffman, B. J. (1983). A simple and very efficient method for generating cDNA libraries. Gene 25, 263-269.

Harris, D. A., Falls, K. L., and Fischbach, G. D. (1989). Differential activation of myotube nuclei following exposure to an acetylcholine receptor-inducing factor. Nature 337, 173-176.

Huynh, T. V., Young, R. A., and Davis, R. W. (1985). Construction and screening cDNA libraries in $\lambda \mathrm{gt} 10$ and $\lambda \mathrm{gt} 11$. In DNA Cloning: A Practical Approach. Vol. 1, D. M. Glover, ed. (Oxford: IRL Press) pp. 49-78.
LaPolla, R. J., Mixter-Mayne, K., and Davidson, N. (1984). Isolation and characterization of a CDNA clone for the complete protein coding region of the delta-subunit of the mouse acetylcholine receptor. Proc. Natl. Acad. Sci. USA 81, 7970-7974.

Levitt-Gilmour, T. A., and Salpeter, M. M. (1986). Gradient of extrajunctional acetylcholine receptors early after denervation of mammalian muscle. J. Neurosci. 6, 1606-1612.

Merlie, J. P., and Sanes, J. R. (1985). Concentration of acetylcholine receptor mRNA in synaptic regions of adult muscle fibers. Nature $317,66-68$.

Mishina, M., Takai, T., Imoto, K., Noda, M., Takahashi, T., Numa, S. Methfessel, L., and Sakmann, B. (1986). Molecular distinction between fetal and adult forms of muscle acetylcholine receptor. Nature 321, 406-411.

New, H. V., and Mudge, A. W. (1986). Calcitonin gene-related peptide regulates muscle acetylcholine receptor synthesis. Nature 323 809-811.

Orlowski, I., and Lingrel, J. B. (1988). Tissue specific and developmental regulation of rat $\mathrm{Na}$,K-ATPase catalytic $\alpha$-isoform and B-subunit mRNAs. J. Biol. Chem. 263, 10436-10442.

Popot, J.-L., and Changeux, J.-P. (1984). The nicotinic acetylcholine receptor: structure of an oligomeric membrane protein. Physiol. Rev. 64, 1162-1239.

Role, L. W., Matossian, V. R., O'Brien, R. J., and Fischbach, G. D. (1985). On the mechanism of acetylcholine receptor accumulation at newly formed synapses on chick myotubes. I. Neurosci. 5 , 2197-2204

Salpeter, M. M., Marchaterre, M., and Harris, R. (1988). Distribution of extrajunctional acetylcholine receptors on a vertebrate muscle: evaluated by using a scanning electron microscope autoradiographic procedure. I. Cell Biol. 106, 2087-2093.

Sanger, F., Nicklen, S., and Coulson, A. R. (1977). DNA sequencing with chain-terminating inhibitors. Proc. Natl. Acad. Sci. USA 74 5463-5467.

Schuetze, S. M., and Role, L. W. (1987). Developmental regulation of nicotinic acetylcholine receptors. Annu. Rev. Neurosci. 10 403-457.

Ziskind-Conhaim, L., Geffen, 1., and Hall, Z. W. (1984). Redistribu tion of acetylcholine receptor accumulation at newly formed synapses on chick myotubes. J. Neurosci. 5, 2197-2204 